\title{
Low and unequal use of outpatient health services in public primary health care facilities in southern Ethiopia: a facility- based cross-sectional study
}

\author{
Hiwot Abera Areru $^{1,2^{*}}$ (D) Mesay Hailu Dangisso ${ }^{1}$ (D) and Bernt Lindtjørn ${ }^{1,2}$ (D)
}

\begin{abstract}
Background: Outpatient department visits per individual for each year are one of the core indicators of healthcare delivery to assess accessibility or quality of services. In addition, this study aimed to assess health service utilisation and disease patterns in southern Ethiopia, by including the health authorities' suggestions to improve the services. No study has assessed this in Ethiopia previously.

Methods: An institution-based cross-sectional design study was done in 65 primary health care units in Dale and Wonsho districts, in Sidama region, for all patients visiting health facilities from 1 July 2017 to 30 June 2018. We estimated the utilisation rate as visits per person per year, the odds ratio for health use and proportions of diseases' diagnoses. The results of our study were presented to local health authorities, and their suggestions for improvements were incorporated into the analysis.

Result: A total of 81,129 patients visited the health facilities. The annual outpatient health service utilisation was 0.18 (95\% Cl: 0.18-0.19) new visits per person per year. The health service utilisation rate per year for the rural population was lower than the urban utilisation by $91 \%(\mathrm{OR}=0.09 ; 95 \% \mathrm{Cl}: 0.08-0.09)$. Children in the age group of $5-14$ years had lower odds of health service utilisation by $78 \%(\mathrm{OR}=0.22 ; 95 \% \mathrm{Cl}: 0.21-0.23)$, compared to children under 5 years of age. Females were four times $(\mathrm{OR}=4.17 ; 95 \% \mathrm{Cl}$ : 4.09-4.25) more likely to utilise health services than males. Febrile illness constituted $17.9 \%(14,847$ of 83,148$)$ of the diagnoses in all age groups. Almost half of the febrile cases, $46.5 \%$ (3827 of 8233), were among children under 5 years of age. There were very few cases of noncommunicable diseases diagnosed in the health facilities. The health authorities suggested improving diagnostic capacities at health centres, enhancing health professionals' skill and attitudes, and improving affordability and physical accessibility of the services.
\end{abstract}

Conclusion: The health service utilisation rate was low in Sidama. The use of health services was lower among rural residents, men, children and elderly, and health post users. Improving the quality, affordability and accessibility of the health services, by involving responsible stakeholders could increase service usage.

\footnotetext{
*Correspondence: hiwotab_2005@yahoo.com

'School of Public Health, College of Medicine and Health Sciences, Hawassa University, P.O.BOX: 1560, Hawassa, Ethiopia

${ }^{2}$ Global Public Health and Primary Care, Centre for International Health,

University of Bergen, Bergen, Norway
}

(c) The Author(s). 2021 Open Access This article is licensed under a Creative Commons Attribution 4.0 International License, which permits use, sharing, adaptation, distribution and reproduction in any medium or format, as long as you give appropriate credit to the original author(s) and the source, provide a link to the Creative Commons licence, and indicate if changes were made. The images or other third party material in this article are included in the article's Creative Commons licence, unless indicated otherwise in a credit line to the material. If material is not included in the article's Creative Commons licence and your intended use is not permitted by statutory regulation or exceeds the permitted use, you will need to obtain permission directly from the copyright holder. To view a copy of this licence, visit http://creativecommons.org/licenses/by/4.0/. The Creative Commons Public Domain Dedication waiver (http://creativecommons.org/publicdomain/zero/1.0/) applies to the data made available in this article, unless otherwise stated in a credit line to the data. 
Keywords: Health service utilisation, Outpatient department visit, Service users' involvement, Patient and public involvement, Health authorities, Diagnostic capacity, Sidama, Southern Ethiopia

\section{Background}

According to the World Health Organization, "health services include all services dealing with the promotion, maintenance and restoration of health. They include both personal- and population-based health services" [1]. Half of the world's people lack some or all essential health services [2]. Health service utilisation data can be obtained from national population surveys, health facility reports and routinely collected demographic and health surveys [3]. The health system indicators used to measure the health service utilisation in Ethiopia include, annual outpatient (OPD) attendance per individual, admission rates, bed occupancy rates and average length of stay [4].

Primary healthcare units constitute health centres and health posts, which are the foundation of the Ethiopian health system; primary hospitals are also included in the primary-level healthcare system [5]. Even though the Ethiopian health and health service system has improved in the last 20 years, most of the goals related to healthy lives and well-being have not yet been achieved [6-8]. Advances have been made in interventions like family planning, antenatal care, maternal healthcare, and hygiene and sanitation since the introduction of health extension workers who are deployed in health posts [9]. However, like other low- and middle-income countries, Ethiopia is still facing a triple burden of disease, with communicable diseases, non-communicable diseases and injuries being the main challenges [5]. The essential health service package of Ethiopia serves as a primary framework of achieving universal health coverage through quality primary health care services. The newly revised Ethiopian essential health service package included nine priority areas based on the burden of disease in the country. These includes reproductive, maternal, neonatal, child and adolescent health, major communicable diseases (HIV/AIDS, tuberculosis and malaria), non-communicable diseases, surgical and injury care, emergency and critical care, neglected tropical diseases, hygiene and environmental health services, health education and behaviour change communication services and multi-sectoral nutrition interventions [10].

Ethiopia aims at improving utilisation of healthcare services in an equitable and accessible manner [5]. Besides, universal health coverage aims to guarantee that all individuals get access to needed, important and adequate quality health services, while being protected from undue financial hardships $[5,11]$. The Federal Ministry of Health has given priority to maternal and child health, and also to family planning, followed by malaria eradication [6,7]. Although official documents suggest that the health service coverage of the country has reached $98 \%$, the performance on major health indicators remains far below the targets set by the government $[5,8]$. In addition, a recent study on universal health coverage showed a national coverage of $34 \%$, with great regional variability [12]. Moreover, the national household health service utilisation survey showed that among people who reported being ill, only $53 \%$ visited health facilities. The common reasons for not seeking care were cost, proximity, self-medication and the thought of diseases as not series [13].

Outpatient service utilisation, as measured by the number of outpatient department (OPD) visits per person per year, is one of the recommended core indicators of health service delivery [14]. Low rates of outpatient visits are indicative of limited accessibility or low quality of services [15]. A study done in 130 countries in 2016 showed that the global outpatient age-standardised utilisation rate was 5.4 visits per individual per year [16]. In 2015, the average OPD visits rate in Ethiopia was 0.48 visit per person per year; however, the target was two visits per person per year by 2020 [5, 17]. The World Health Organization recommends around three to four OPD visits per person per year [18].

The rate and type of health service utilisation can be directly or indirectly affected by certain demographic attributes; these include age, sex, marital status, education, and income. The change that occurred in the health service utilisation pattern in the developed world, like the United States of America, is partly due to such changes in demographic characteristics of the population [19]. The same holds true in other Sub-Saharan Africa countries [20, 21].

Even though involving stakeholders, such as health service providers and authorities, has been a common practice in developed nations' studies, it has only recently been given some attention in Africa $[22,23]$. The combined effort of the service providers or health authorities, users and researchers can be useful in creating insight into the problems and provide a framework for remedial implementation, thereby improving the quality and impact of health research [23-25]. It is believed that health authorities will make decisions with policy implications after they critically evaluate the potential benefits for the improvement of primary health services [26]. Therefore, to ensure the implementation of research findings and bring change in legislation that can impact 
the quality of healthcare, it is mandatory to make such a process interactive and evidence-based, to build trust and understanding between the researchers and policymakers at local, regional and national levels [27, 28]. In this study, the stakeholders were given the result from their own facilities, and were asked to comment and suggest possible ways to improve the services at their institutions [29].

To our knowledge, in Ethiopia, there has been only one study 30 years ago that assessed the overall utilisation of health services as visits per individual per year. Besides this, there are no studies that presented the result of a study to the health authorities and included their opinions and recommendations as part of the investigation in Ethiopia. The objective of this study was to assess the health service utilisation and disease patterns in southern Ethiopia. In addition, we sought to get the local health authorities' suggestions to improve the health services in the area.

\section{Methods}

\section{Study design and period}

The study employed an institution-based cross-sectional study design and included all patients visiting these public health centres and health posts from 1 July 2017 to 30 June 2018 (1 year).

\section{Setting}

The Sidama region is one of the most densely populated areas in Ethiopia, with 533 persons $/ \mathrm{km}^{2}$ [30, 31]. The region constitutes about $4.0 \%$ of the national population [32]. Agriculture is a prominent economic sector with 'enset' (E. ventricosum) and maize as the main foods, and coffee and fruits as the most important cash products. 'Khat', a form of chewable stimulant, is another cash crop widely produced [33].

We did the study in Dale and Wonsho districts (woredas). In 2017, the Dale district has a total population of 268,839 people and an estimated 53,768 households. It has 36 rural and two urban kebeles (the lowest administrative structures). Yirga Alem town is the main town in the district and has five urban kebeles. Wonsho district has 129,730 people living in 17 rural and one urban kebeles in 21,857 households [33, 34]. There are ten health centres and 33 health posts in Dale, and the Wonsho district has five health centres and 17 health posts [33, 34]. Even though there are two private clinics in rural Dale and one in Wonsho district, we believe most rural communities seek health services from governmental institutions [35]. Therefore, we studied all 65 governmental healthcare facilities available in Dale and Wonsho districts.

\section{Participants}

All sixty-five primary health care units (15 health centres and 50 health posts) in Dale and Wonsho districts were included in our study. Moreover, the health officials, from local to regional health facilities and offices, participated in this study. Seven health professionals were selected purposively so that they could comment and suggest ways to improve the health services of the primary health care institutions. These health professionals were: one from each of the district health departments, one from rural health centres from each district, one from urban health centres from each district, and one health professional from the Sidama Regional Health Bureau.

\section{Study size}

Assuming the national individual utilisation rate per year of OPD visit, as $48 \%$ prevalence, a power of $80,95 \%$ confidence interval, a margin of error of $1.4 \%$ and the ratio of sample size in unexposed/exposed of 1 , the required sample size was 4869 patients. The cases included in this study, however, were 81,129. Participants from health facilities and offices were selected purposively due to their position and involvement in decision-making processes.

\section{Variables and data collection procedure}

The main outcome measures were visits to primary health care units per person per year and the proportions of diagnoses. The exposure variables were gender, age, residence (urban or rural), district, type of health facility, disease types and visit types (new or repeat).

Fifteen local data collectors with a diploma in nursing and two supervisors with BSc degrees were trained to collect the data from the institutional registries at each health centre and health post. Standard registers supplied by the Federal Ministry of Health to the health centres and health posts were reviewed. Each unit or department had registry with the registration, identification and service-related information. The lists of the registries and the major components reviewed are attached as Table 8 , additional file 1 .

The diagnoses made by the health workers in health centres were mainly clinically, using guidelines, such as Integrated Management of Childhood Illness (IMCI), and sometimes supported by laboratory services. The health extension workers made diagnoses based on the working manuals, such as Integrated Community Case Management (iCCM) of malaria, pneumonia and diarrhoea, and TB (tuberculosis) screening guidelines. Then, the diagnoses obtained from the registry of health facilities were categorised according to the national or international disease classification (ICD) during data cleaning $[36,37]$. 
At three institutions, complete data couldn't be found; in the delivery unit of Gidamo health centre, and the registration record for 5 months was not found. Similarly, in Bera health centre, data on delivering mothers for 5 months were missing. Besides, the information from the eye clinic at Bokaso health centre was not found because it was locked during the data collection period.

Since involvement of the health authorities was a secondary focus of this study, the Guidance for Reporting Involvement of Patients and the Public 2-short form were used as guides to collect, analyse and present the data from the health authorities [29]. After analysis, the results were presented to Dale and Wonsho district health office managers, and to the urban and rural health centre managers, and to the Sidama Regional State Health Bureau. They were informed about the results of our study and were asked to suggest areas of possible improvements. Two data collectors with BSc degree interviewed the respondents (one for each district). They were all encouraged to give their feedback based on the results and to suggest possible areas of improvements.

\section{Data analysis}

The data collection instruments were pretested on health centres and health posts outside of both districts. The data collectors were trained for 2 days about the protocol and how to extract the data from the registries. Re-checking was done by the principal investigator on $5 \%$ of the cases in each health facility, to assure the quality of the data.

The data were double entered and validated in EpiData version 3.1 software (EpiData Association Odense, Denmark). The analysis was done by STATA software version 13 (Stata Corp., LLC. College Station, Texas, USA). Descriptive statistics were done for all cases and variables. Stratification was done based on background characteristics of the clients on service utilisation and disease diagnosis. We used the number of new visitors to calculate the odds ratio and $95 \%$ confidence interval and compare the rate of utilisation for each explanatory variable. The WHO core health indicators manual was used to calculate outpatient utilisation rate [14].

The denominators for the utilisation rate calculations were based on projections of the 2007 census done in Sidama [38]. Thus, we obtained the estimated population for the year $2017 / 18$ for women, children under 5 years of age, infants (under 1 year of age), people older than 5 years of age, and sex ratio.

Based on these population estimates, we calculated the utilisation rates as new visits per person per year for each age group, sex, family planning, antenatal care, postnatal care, delivery, pneumonia, diarrhoea and malnutrition. Microsoft Excel and MedCalc Software version 19.2.6 (MedCalc Software Ltd., Ostend,Belgium) were used to calculate these rates. Tables and figures were used to display the findings.

Missing information was identified on three of the variables (visit type, sex and age). We coded the missing values as "not recorded". Hence, the utilisation rate was calculated for new cases only.

Each of the health staff gave their feedback on the results. Their feedback was analysed manually. First, we read and re-read their responses to identify similar ideas and then we categorised them based on the emerging themes. Following this, we separately organised them as district and regional authorities' responses under each themes. Finally, the quotes were organised under each theme in the summarised table.

\section{Operational definitions}

More definitions are attached in additional file 2.

Outpatient utilisation rate: The number of new outpatient visits to health facilities per year relative to the total population of the same geographical area.

We calculated the utilisation rates for each variable as: The number of disease events divided by the eligible population of the same geographic area. We estimated the proportion of eligible population by multiplying the total population of the districts by the percentage of a particular category obtained from census and surveys.

For annual immunisation utilisation rate the denominator was the cohort of children in a year. We divided the number of under-five year children in the study area by five to obtain a single year children since we collected the data for children immunised in 1 year.

New visitors were defined as those patients who attended the health facility for the first time. Repeat visitors were those who attended the health facility for multiple times for the same diagnoses or illness within the reporting period, one Ethiopian fiscal year (July to June) and registered once as new visitor [39].

For family planning service: "New acceptors" refers to the number of modern contraceptive method acceptors who receive family planning services from a recognised family planning providing facility for the first time irrespective of the method used. Each such acceptor was counted once. Each "repeat acceptor" is counted once, irrespective of number of times family planning services were received during that fiscal year [39].

For immunisation services, new visitors were those who received their first dose of vaccines and repeat visitors were those who received more than one dose in 1 year.

For antenatal care service those clients who present for the first follow-up visit in a year were considered as new visitors. Those clients who came for subsequent 


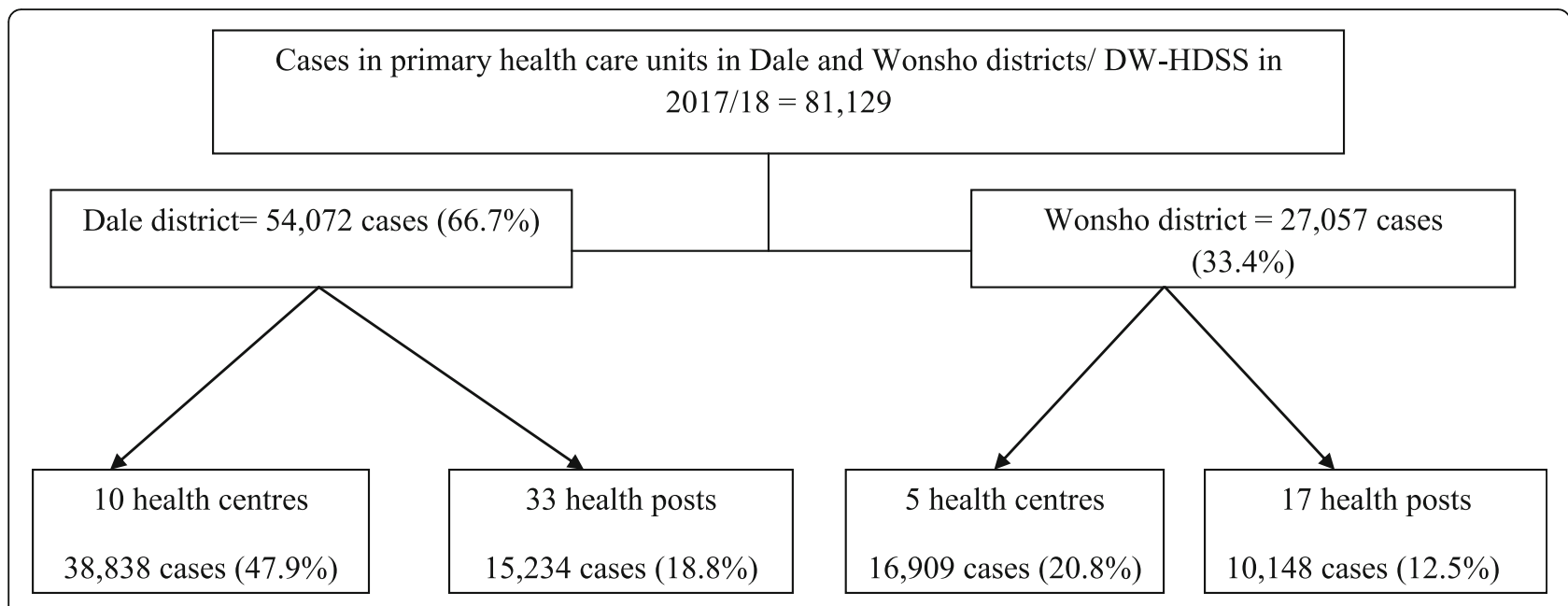

Fig. 1 Flowchart of case distribution in Dale and Wonsho districts, 2017/18, Sidama, Ethiopia $(N=81,129)$

Table 1 Background characteristics of clients visiting health facilities in Dale and Wonsho districts, 2017/18, Sidama, Ethiopia $(N=81,129)$

\begin{tabular}{|c|c|c|}
\hline Variables & Number of cases $(N=81,129)$ & $\%$ \\
\hline \multicolumn{3}{|l|}{ Type of health facility } \\
\hline Health centres' cases & 55,747 & 68.7 \\
\hline Health posts' cases & 25,382 & 31.3 \\
\hline \multicolumn{3}{|l|}{ Residence } \\
\hline Rural & 66,341 & 81.8 \\
\hline Urban & 14,788 & 18.2 \\
\hline \multicolumn{3}{|l|}{ District } \\
\hline Wonsho & 27,057 & 33.3 \\
\hline Dale & 54,072 & 66.7 \\
\hline \multicolumn{3}{|l|}{ Sex } \\
\hline Female & 59,822 & 73.7 \\
\hline Male & 20,232 & 25.0 \\
\hline Not recorded & 1075 & 1.3 \\
\hline \multicolumn{3}{|l|}{ Type of visit } \\
\hline New & 73,513 & 90.6 \\
\hline Repeat & 1048 & 1.3 \\
\hline Not recorded & 6568 & 8.1 \\
\hline \multicolumn{3}{|l|}{ Age group (in years) } \\
\hline Under 5 & 13,112 & 16.2 \\
\hline $5-14$ & 4788 & 5.9 \\
\hline $15-24$ & 17,729 & 21.9 \\
\hline $25-34$ & 30,172 & 37.2 \\
\hline $35-44$ & 5268 & 6.5 \\
\hline $45-54$ & 1754 & 2.2 \\
\hline $55-64$ & 826 & 1.0 \\
\hline $65-74$ & 335 & 0.4 \\
\hline $75+$ & 208 & 0.3 \\
\hline Age missing & 6937 & 8.6 \\
\hline
\end{tabular}

follow-ups were repeat visitors; however, they are counted only once.

\section{Results}

\section{Background information}

More than two-thirds of the cases (69\%) received service or treatment from health centres. Two-thirds (67\%) of the cases were from Dale district (Fig. 1).

The total number of the clients who visited the health facilities was 81,129 . Most of the clients were female (74\%) and were from rural areas (82\%). The mean age of the clients was 21.9 years (range: $0-120$ ). About a third (37\%) of the cases were in the age group of $25-34$ years (Table 1).

\section{Utilisation rates}

The annual outpatient health service utilisation rate was 0.18 (95\% CI: 0.18-0.19) for new visitors. The number of new visits per year for rural people was 0.16 (95\% CI: 0.15-0.16) and 0.68 (95\% CI: 0.67-0.69) for urban population. Therefore, the rural population visited health institutions 11 times less than urban people $(\mathrm{OR}=0.09$; 95\% CI: $0.08-0.09)$. Children in the age group of $5-14$ years had lower odds of health service utilisation by $78 \%$ $(\mathrm{OR}=0.22$; 95\% CI: 0.21-0.23), when compared to children under 5 years. Similarly, the odds of health service utilisation was lower for people aged above 75 years by $69 \%(\mathrm{OR}=0.31 ; 95 \% \mathrm{CI}: 0.27-0.36)$, compared to children under 5 years. Females were 4.17 (95\% CI: 4.094.25) times more likely to utilise health services than males (Table 2).

\section{Prevalence of maternal health services utilisation}

The prevalence of family planning utilisation was $28.3 \%$ $(22,384$ family planning users divided by the number of fertile women in the districts which was 79,076 (398,569 
Table 2 Utilisation rates by new clients' characteristics in Dale and Wonsho district primary health care units (PHCUs), 2018, Sidama, Ethiopia $(N=73,513)$

\begin{tabular}{|c|c|c|c|c|c|c|c|}
\hline \multirow[t]{2}{*}{ Variables } & \multicolumn{2}{|c|}{ Utilised health service } & \multirow{2}{*}{$\begin{array}{l}\text { Estimated } \\
\text { total } \\
\text { number of } \\
\text { eligible } \\
\text { population }\end{array}$} & \multirow{2}{*}{$\begin{array}{l}\% \text { (out } \\
\text { of } \\
73,513 \\
\text { new } \\
\text { cases) }\end{array}$} & \multirow{2}{*}{$\begin{array}{l}\text { Rates of } \\
\text { utilisation } \\
(95 \% \mathrm{Cl})\end{array}$} & \multirow{2}{*}{$\begin{array}{l}\text { Odds ratio } \\
(95 \% \mathrm{Cl})\end{array}$} & \multirow[t]{2}{*}{$P$-value } \\
\hline & Yes & No & & & & & \\
\hline \multicolumn{8}{|l|}{ Health facilities } \\
\hline Health centres' cases & 50,275 & 348,294 & 398,569 & 68.7 & $0.13(0.12-0.13)$ & $2.33(2.29-2.37)$ & $P<0.0001$ \\
\hline Health posts' cases & 23,238 & 375,331 & 398,569 & 31.3 & $0.06(0.05-0.06)$ & 1 & \\
\hline \multicolumn{8}{|l|}{ Residence } \\
\hline Rural & 59,929 & 318,712 & 378,641 & 81.8 & $0.16(0.15-0.16)$ & $0.09(0.08-0.09)$ & $P<0.0001$ \\
\hline Urban & 13,584 & 6345 & 19,929 & 18.2 & $0.68(0.67-0.69)$ & 1 & \\
\hline \multicolumn{8}{|l|}{ Districts } \\
\hline Wonsho & 25,066 & 104,664 & 129,730 & 34.1 & $0.19(0.19-0.20)$ & 1 & $P<0.0001$ \\
\hline Dale & 48,447 & 220,392 & 268,839 & 65.9 & $0.18(0.17-0.18)$ & $0.92(0.90-0.93)$ & \\
\hline \multicolumn{8}{|l|}{ Sex } \\
\hline Female & 55,159 & 141,180 & 196,339 & 75.0 & $0.28(0.27-0.28)$ & $4.17(4.09-4.25)$ & $P<0.0001$ \\
\hline Male & 17,334 & 184,896 & 202,230 & 23.6 & $0.09(0.08-0.09)$ & 1 & \\
\hline Not recorded & 1020 & - & - & 1.4 & - & & \\
\hline \multicolumn{8}{|l|}{ Age group } \\
\hline Under 5 & 8936 & 53,293 & 62,229 & 12.2 & $0.14(0.14-0.15)$ & 1 & \\
\hline $5-14$ & 4508 & 124,039 & 128,547 & 6.1 & $0.04(0.03-0.04)$ & $0.22(0.21-0.23)$ & $P<0.0001$ \\
\hline $15-24$ & 17,125 & 59,678 & 76,803 & 23.3 & $0.22(0.22-0.23)$ & $1.71(1.66-1.76)$ & $P<0.0001$ \\
\hline $25-34$ & 28,816 & 25,178 & 53,994 & 39.2 & $0.53(0.53-0.54)$ & $6.83(6.64-7.02)$ & $P<0.0001$ \\
\hline $35-44$ & 4512 & 31,517 & 36,029 & 6.1 & $0.13(0.12-0.13)$ & $0.85(0.82-0.89)$ & $P<0.0001$ \\
\hline $45-54$ & 1536 & 19,036 & 20,572 & 2.1 & $0.07(0.07-0.08)$ & $0.48(0.45-0.51)$ & $P<0.0001$ \\
\hline $55-64$ & 762 & 9896 & 10,658 & 1.0 & $0.07(0.07-0.08)$ & $0.46(0.43-0.50)$ & $P<0.0001$ \\
\hline $65-74$ & 312 & 5624 & 5936 & 0.4 & $0.05(0.05-0.06)$ & $0.33(0.29-0.37)$ & $P<0.0001$ \\
\hline $75+$ & 189 & 3652 & 3801 & 0.3 & $0.05(0.04-0.06)$ & $0.31(0.27-0.36)$ & $P<0.0001$ \\
\hline Age missing & 6817 & - & - & 9.3 & - & & \\
\hline Total & 73,513 & 331,873 & 398,569 & 100 & $0.18(0.18-0.19)$ & & \\
\hline
\end{tabular}

*19.84\%)). Most of the family planning service clients, $73.6 \%$ (16,481 of 22,384 clients), used short-acting contraceptives, which include Depo-Provera or medroxy progesterone acetate, contraceptive pills (combined or progesterone-only oral contraceptives), and condoms. Long-acting contraceptives, such as Intra-Uterine Contraceptive Device (IUCD) and implants, were used by $26.3 \%$ (5894 of 22,384 clients). Yet, only nine of $22,384(0.04 \%)$ patients chose a permanent contraceptive method such as bilateral tubal ligation.

The utilisation of antenatal care service in this study was 45\% (6206 antenatal care clients per an estimated 13,791 pregnant mothers in the districts $(398,569$ *3.46\%) ) and delivery service utilisation was 40.7\% (5619 delivering mothers per an estimated 13,791 pregnant mothers in the districts). Postnatal care service utilisation in this study was $14.3 \%$ (1973 mothers and children who received postnatal care per an estimated 13,791 pregnant mothers in the districts).

\section{Treatment at departments}

Of the departments that provided health services, 30\% $(24,388$ of 81,129 cases) received service from the adult outpatient department. Family planning service was the next most utilised service, constituting 28\% (22,423 of $81,129)$ of the cases. The stabilisation centre for malnutrition was the least common of the services, utilised by 33 of $81,129(0.04 \%)$ of the visitors (Table 6 is attached as additional file 3$)$.

\section{Caseloads/diagnosis}

Table 3 shows that clients coming to get contraceptive services constitute $26.9 \%(22,384$ of 83,149$)$ of the caseload. Typhoid and typhus fever were the most common 
Table 3 Recorded diagnoses by age group, sex, type of health facility and visit type of the cases in Dale and Wonsho districts primary health care units in 2018, Sidama, Ethiopia $(N=83,149)$

\begin{tabular}{|c|c|c|c|c|c|c|c|c|c|c|c|c|c|c|}
\hline \multirow[t]{2}{*}{ Diagnosis } & \multirow{2}{*}{$\begin{array}{l}\text { Number } \\
\text { of } \\
\text { diagnoses }\end{array}$} & \multirow{2}{*}{$\%$} & \multicolumn{3}{|c|}{ Age group } & \multicolumn{3}{|l|}{ Sex } & \multicolumn{2}{|c|}{$\begin{array}{l}\text { Type of health } \\
\text { facility }\end{array}$} & \multicolumn{3}{|c|}{ Type of visit } & \multirow{2}{*}{$\begin{array}{l}\text { Total } \\
\text { number } \\
\text { of } \\
\text { clients }\end{array}$} \\
\hline & & & $\begin{array}{l}<5 \\
\text { years }\end{array}$ & $\begin{array}{l}5- \\
14 \\
\text { years }\end{array}$ & $\begin{array}{l}\geq 15 \\
\text { years }\end{array}$ & Male & Female & Missing & $\frac{\text { Health }}{\text { centre }}$ & $\frac{\text { Health }}{\underline{\text { post }}}$ & $\underline{\text { New }}$ & $\underline{\text { Repeat }}$ & $\underline{\text { Missing }}$ & \\
\hline Family planning & 22,384 & 26.9 & 0 & 0 & 18,936 & 0 & 22,384 & 0 & 12,039 & 10,345 & 22,384 & 0 & 0 & 22,384 \\
\hline Immunisation & 7549 & 9.1 & 4193 & 0 & 540 & 3188 & 3471 & 890 & 1197 & 6352 & 7549 & 0 & 0 & 7549 \\
\hline Antenatal care & 6206 & 7.5 & 0 & 0 & 5878 & 0 & 6206 & 0 & 2915 & 3291 & 6206 & 0 & 0 & 6206 \\
\hline Delivery & 5619 & 6.8 & 0 & 0 & 5600 & 0 & 5619 & 0 & 5619 & & 5619 & 0 & 0 & 5619 \\
\hline $\begin{array}{l}\text { Typhoid and Typhus } \\
\text { fever }\end{array}$ & 4931 & 5.9 & 6 & 337 & 4210 & 1948 & 2604 & 3 & 4931 & & 4672 & 86 & 173 & 4555 \\
\hline Pneumonia & 4072 & 4.9 & 2828 & 495 & 713 & 2071 & 1992 & 9 & 2735 & 1337 & 2695 & 240 & 1137 & 4072 \\
\hline $\begin{array}{l}\text { Parasitic and } \\
\text { helminthic infections }\end{array}$ & 3660 & 4.4 & 287 & 840 & 2519 & 1790 & 1854 & 7 & 3620 & 40 & 3298 & 72 & 290 & 3651 \\
\hline Fever and febrile illness & 3895 & 4.7 & 527 & 629 & 2709 & 1703 & 2181 & 11 & 3844 & 51 & 3363 & 97 & 435 & 3895 \\
\hline $\begin{array}{l}\text { Upper and lower } \\
\text { respiratory disorders }\end{array}$ & 2930 & 3.5 & 877 & 487 & 1516 & 1446 & 1457 & 9 & 2645 & 285 & 2262 & 48 & 620 & 2912 \\
\hline $\begin{array}{l}\text { Accident (burn, trauma, } \\
\text { injury, road traffic } \\
\text { accident) }\end{array}$ & 2609 & 3.1 & 80 & 567 & 1952 & 1708 & 880 & 21 & 2608 & 1 & 2465 & 24 & 120 & 2609 \\
\hline $\begin{array}{l}\text { Screening for cancer, } \\
\text { human } \\
\text { immunodeficiency } \\
\text { virus and helminths }\end{array}$ & 2567 & 3.1 & 78 & 2 & 2464 & 24 & 2540 & 3 & 2437 & 130 & 1148 & 0 & 1419 & 2567 \\
\hline Diarrhoea & 2311 & 2.8 & 1371 & 199 & 718 & 1132 & 1175 & 4 & 1768 & 543 & 1659 & 96 & 556 & 2311 \\
\hline $\begin{array}{l}\text { Postnatal care and } \\
\text { home visit }\end{array}$ & 1973 & 2.4 & 1079 & 0 & 830 & 583 & 1347 & 43 & 585 & 1388 & 1783 & 11 & 179 & 1973 \\
\hline Malaria (all types) & 1949 & 2.3 & 388 & 523 & 984 & 1017 & 913 & 19 & 1520 & 429 & 1649 & 55 & 245 & 1949 \\
\hline $\begin{array}{l}\text { Genito-urinary } \\
\text { disorders and } \\
\text { complaints }\end{array}$ & 1820 & 2.2 & 2 & 81 & 1731 & 781 & 1035 & 3 & 1820 & & 1715 & 47 & 59 & 1819 \\
\hline $\begin{array}{l}\text { Gastro-intestinal } \\
\text { disorders and } \\
\text { complaints }\end{array}$ & 1733 & 2.1 & 76 & 84 & 1564 & 645 & 1084 & 1 & 1733 & & 1577 & 46 & 110 & 1730 \\
\hline Skin disorders & 1240 & 1.5 & 302 & 329 & 603 & 691 & 547 & 1 & 1180 & 60 & 1054 & 35 & 151 & 1239 \\
\hline Malnutrition & 729 & 0.9 & 705 & 22 & 0 & 351 & 372 & 6 & 59 & 670 & 256 & 70 & 403 & 729 \\
\hline Tuberculosis (all types) & 561 & 0.7 & 6 & 36 & 516 & 285 & 269 & 6 & 488 & 73 & 442 & 26 & 93 & 560 \\
\hline Abortion & 553 & 0.7 & 0 & 0 & 547 & 0 & 553 & 0 & 553 & & 138 & 0 & 415 & 553 \\
\hline $\begin{array}{l}\text { Musculoskeletal } \\
\text { disorders }\end{array}$ & 412 & 0.5 & 1 & 17 & 392 & 264 & 147 & 0 & 412 & & 394 & 4 & 13 & 411 \\
\hline Eye problems & 389 & 0.5 & 41 & 34 & 310 & 208 & 151 & 27 & 381 & 8 & 330 & 4 & 55 & 386 \\
\hline Hypertension & 304 & 0.4 & 0 & 5 & 299 & 114 & 190 & 0 & 304 & & 270 & 27 & 7 & 304 \\
\hline $\begin{array}{l}\text { Obstetric and } \\
\text { gynaecologic cases }\end{array}$ & 270 & 0.3 & 0 & 3 & 265 & 0 & 269 & 0 & 270 & & 233 & 1 & 38 & 269 \\
\hline Bacterial infection & 366 & 0.4 & 267 & 30 & 63 & 179 & 185 & 2 & 154 & 212 & 236 & 30 & 100 & 366 \\
\hline $\begin{array}{l}\text { Ear and mastoid } \\
\text { disorders }\end{array}$ & 185 & 0.2 & 87 & 23 & 73 & 83 & 99 & 2 & 152 & 33 & 149 & 5 & 31 & 184 \\
\hline $\begin{array}{l}\text { Sexually transmitted } \\
\text { infections or human } \\
\text { immunodeficiency } \\
\text { virus }\end{array}$ & 185 & 0.2 & 0 & 5 & 175 & 72 & 108 & 0 & 185 & & 177 & 5 & 2 & 180 \\
\hline
\end{tabular}


Table 3 Recorded diagnoses by age group, sex, type of health facility and visit type of the cases in Dale and Wonsho districts primary health care units in 2018, Sidama, Ethiopia $(N=83,149)$ (Continued)

\begin{tabular}{|c|c|c|c|c|c|c|c|c|c|c|c|c|c|c|}
\hline \multirow[t]{2}{*}{ Diagnosis } & \multirow{2}{*}{$\begin{array}{l}\text { Number } \\
\text { of } \\
\text { diagnoses }\end{array}$} & \multirow[t]{2}{*}{$\%$} & \multicolumn{3}{|c|}{ Age group } & \multicolumn{3}{|l|}{ Sex } & \multicolumn{2}{|c|}{$\begin{array}{l}\text { Type of health } \\
\text { facility }\end{array}$} & \multicolumn{3}{|c|}{ Type of visit } & \multirow{2}{*}{$\begin{array}{l}\text { Total } \\
\text { number } \\
\text { of } \\
\text { clients }\end{array}$} \\
\hline & & & $\begin{array}{l}<5 \\
\text { years }\end{array}$ & $\begin{array}{l}5- \\
14 \\
\text { years }\end{array}$ & $\begin{array}{l}\geq 15 \\
\text { years }\end{array}$ & Male & Female & Missing & $\frac{\text { Health }}{\text { centre }}$ & $\frac{\text { Health }}{\text { post }}$ & New & Repeat & Missing & \\
\hline $\begin{array}{l}\text { Dental and oral } \\
\text { disorders }\end{array}$ & 83 & 0.1 & 10 & 5 & 68 & 43 & 40 & 0 & 82 & 1 & 75 & 3 & 5 & 83 \\
\hline Anaemia & 51 & 0.1 & 3 & 1 & 47 & 12 & 39 & 0 & 51 & & 47 & 1 & 3 & 51 \\
\hline Other & 1613 & 1.9 & 138 & 193 & 1267 & 602 & 1002 & 8 & 1454 & 158 & 1432 & 45 & 135 & 1612 \\
\hline
\end{tabular}

registered ailments, contributing to $5.9 \%$ (4931 of 83,149 ) of the diagnoses, with $92 \%$ (4210 of 4555 cases) above the age of fifteen; $57 \%$ of these were females (2604 of 4555 cases). From non-communicable diseases, hypertension was diagnosed in $0.4 \%$ (304 of 83,149$)$ and $63 \%$ (190 of 304) of these were females.

\section{Caseloads in children}

Of the 16,331 cases of children below 5 years of age, $42.9 \%$ (7010 of 16,331) visited the health facilities for immunisation, and $35.9 \%$ (2520 of 7010 ) of them were fully immunised. The annual immunisation utilisation rate was 56 (95\% CI: 55-58) visit per 100 children per year (7010 visits for an estimated average of 12,446 children in the actual cohort in a single year). For neonates, $6.7 \%$ (1088 of 16,331) came for assessment of danger signs and weight measurements. The rest, $50.4 \%$ (8233 of 16,331 cases), visited the health facilities for different types of illnesses and complaints. Out of these, more than $87 \%$ (7184 of 8233 ) were registered as new visitors. The most common registered diagnosis among children who visited the health facilities was pneumonia, contributing to 2635 of 7184 (36.7\%) of the caseloads (Table 4).

\section{Service provision by sex}

From the departments giving services to both genders, in adult OPD there were more female patients (54\%) than men, whereas in emergency OPD, more than twothirds $(68.0 \%)$ of the patients were male. In the community health day services (CHD), in which services like vitamin A supplementation, de-worming and malnutrition screening are given to the community, the majority $(82 \%)$ were female (Table 7 is attached as additional file 4).

Table 4 Prevalence of the ten most common disease diagnoses of under-five years of age children in Dale and Wonsho districts primary health care units, in 2018, Sidama, Ethiopia $(N=7184)$

\begin{tabular}{|c|c|c|c|c|c|}
\hline Diagnosis & $\begin{array}{l}\text { Total cases } \\
\text { Number (\%) }\end{array}$ & $\begin{array}{l}\text { Number of cases in } \\
\text { Wonsho district }\end{array}$ & $\begin{array}{l}\text { Number of cases in } \\
\text { Dale district }\end{array}$ & $\begin{array}{l}\text { Total under-five years chil- } \\
\text { dren in both districts }\end{array}$ & $\begin{array}{l}\text { Prevalence rate/ } \\
1000 \text { population }\end{array}$ \\
\hline Pneumonia ${ }^{a}$ & $2635(36.7)$ & $996(45.8)$ & $1639(32.7)$ & 62,228 & 42.3 \\
\hline Diarrhoea $^{b}$ & $1281(17.8)$ & $467(21.5)$ & $814(16.3)$ & 62,228 & 20.6 \\
\hline $\begin{array}{l}\text { Other respiratory } \\
\text { problems }^{c}\end{array}$ & $830(11.6)$ & $68(3.1)$ & $762(15.2)$ & 62,228 & 13.3 \\
\hline Febrile illnesses $^{d}$ & $502(7.0)$ & $96(4.4)$ & $406(8.1)$ & 62,228 & 8.1 \\
\hline Malaria $^{e}$ & $376(5.2)$ & $0(0)$ & $376(7.5)$ & 62,228 & 6.0 \\
\hline Malnutrition ${ }^{f}$ & $350(4.9)$ & $169(7.8)$ & 181(3.6) & 62,228 & 5.6 \\
\hline Skin problems ${ }^{g}$ & $257(3.6)$ & $96(4.4)$ & $161(3.2)$ & 62,228 & 4.1 \\
\hline $\begin{array}{l}\text { Parasitic and } \\
\text { helminthic infections }\end{array}$ & $253(3.5)$ & $94(4.3)$ & $159(3.2)$ & 62,228 & 4.1 \\
\hline Bacterial infections ${ }^{i}$ & $273(3.3)$ & $88(4.0)$ & $147(2.9)$ & 62,228 & 4.4 \\
\hline Accidents $^{j}$ & $78(1.0)$ & $47(2.2)$ & $31(0.6)$ & 62,228 & 1.3 \\
\hline Other & $387(5.4)$ & $56(2.6)$ & 331 (6.6) & 62,228 & 6.2 \\
\hline
\end{tabular}

${ }^{\mathrm{a} P n e u m o n i a}=$ all types of pneumonia; ${ }^{\mathrm{b}}$ Diarrhoea = dehydration and all types of diarrhoea; ${ }^{\mathrm{C}}$ Other respiratory problems = upper and lower respiratory disorder; ${ }^{\mathrm{d}}$ Febrile illnesses = all acute febrile illnesses; ${ }^{\mathrm{e}}$ Malaria = all types of malaria; ${ }^{\mathrm{f}}$ Malnutrition = Severe acute and moderate malnutrition, and underweight; ${ }^{9}$ Skin problems = specific and unspecific skin problems; ${ }^{\text {h}}$ Parasitic and helminthic infections = all types of helminths, parasites; ${ }^{\mathrm{B} B a c t e r i a l}$ infection $=$ local and unspecific $^{2}$ bacterial infection and sepsis; ${ }^{\mathrm{j}}$ Accidents = all kinds of injury, trauma and road traffic accidents 
Table 5 Solutions and recommendations forwarded by health professionals in Sidama region on the health service utilisation of Dale and Wonsho districts, 2018, Sidama, Ethiopia

\section{Recommendation from district health officials and health centre \\ Recommendation from Sidama Regional Health Bureau} managers

\section{Theme 1: Budget allocations and alternative sources}

Ensuring and creating awareness on the community-based health insurance scheme.

"Most of the rural community thinks why would I have the communitybased insurance, I might not be sick at all. But in reality our community spends more out of pocket.... Therefore, if we could convince and create awareness about the insurance, the frequency of the visit will increase."

Allocating enough budgets for health facilities; and support those people who are very poor and orphans, and unable to pay for health services through healthcare financing.

"The kebeles should identify genuinely those who are the "poorest of the poor" and provide all services free of charge. Most people don't come to health facility due to financial issue."

\section{Theme 2: Sustainable drug and material supply}

Supplying and ensuring availability of medical supplies or equipment like essential medications, laboratory reagents (diagnostic materials), physical examination apparatuses to provide quality health service.

"The main problem I think is lack of medications in the health centres, because of repeated encounter to get some of the medications from us, the community tends to go to other facilities."

"We don't have functioning blood pressure measurement apparatus, such issues makes it to make accurate diagnosis."

\section{Theme 3: Health workers capacity building}

Creating a compassionate, respectful and caring (CRC) health workforce by giving training and supervision to improve their attitudes.

"Training on CRC will improve the health professionals attitude and patients need such services"

Preparing manuals and give training on different components like community mobilisation.

"Health extension workers need more training so that they can equip the community about the services being given at health post and health centre level"

"Strengthening integrated community case management, community-based newborn care, and integrated management of neonatal and childhood illness services are important to improve the diagnostic capacity."

Provide counselling and on-the-job and refreshment training to health professionals to halt negligence or malpractice by health professionals. "Regular counselling and refreshment trainings should be given to health professionals, this will help in improving malpractices in their day to day practice"

\section{Theme 4: Quality of services}

\section{Theme 5: Access of health facilities}

Strengthening linkages between the district health offices and health centres, and between health centres and health posts, by creating timely and smooth lines of communication.
Ensuring availability of different laboratory tests with high specificity; including hematologic tests for accurately identifying anaemia, diabetes, other infections and febrile illnesses; blood chemistry; urine analysis and culture.

"At the primary health level the availability and quality of laboratory tests in doubtful. The tests, if available, lack specificity. They mostly rely on making diagnosis based on signs or symptoms, and this could lead to misdiagnose or make wrong diagnosis"

Shortage of drugs and other supplies may affect service utilisation, because patients may prefer private clinics rather than government health facilities for these reasons.

"One of the issues here is if someone didn't get drugs or laboratory test from the nearby health centre, he or she will go to other places."

Augment the knowledge and skill of health workers through short- and long-term training.

To improve the diagnostic capacity of health facilities, further training, provision of more laboratory technicians and test kits may be recommended.

"Training whether short term or long term will improve the knowledge and skill of the health professionals, to make accurate diagnoses"
Working to make the health facilities function per the standards will increase the quality of care, which intern will improve the utilisation. "For example, stabilisation centre service utilisation for severely malnourished children is low. This may be due to the fact that not all health centres and hospitals are providing services as per standard due to shortage of meals for caretakers, lack of trained staff and shortage of stabilisation centre kits. Therefore, working to mitigate these factors in collaboration with other stakeholders might be a solution."

Building maternity waiting rooms will improve access related problem. "The lower postnatal care utilisation shows that almost all primary health care units are not keeping mothers at the health facilities at least for $24 \mathrm{~h}$ after delivery. This may be due to a shortage of maternity waiting rooms 
Table 5 Solutions and recommendations forwarded by health professionals in Sidama region on the health service utilisation of Dale and Wonsho districts, 2018, Sidama, Ethiopia (Continued)

because most government health facilities have incomplete premises and infrastructure."

Plan to increase the number of health facilities.

"Due to the geographical inaccessibility of our woreda (Wonsho), more health facilities should be constructed to increase utilisation"

\section{Theme 6: Public and stakeholders involvement and collaboration}

The public should be involved from planning to implementation of health services. The health extension workers also should focus on creating awareness on health care seeking behaviour. Every gathering should be taken as a venue for awareness creation. Moreover, collaboration with other non-governmental organisations might alleviate problems with capacity building, material supply and infrastructure. "Involving women health development armies, who are volunteer community health workers responsible for mobilising the community, during planning and training them on implementation issues."

"Encourage health extension workers to strictly work on house-to-house visits and educating the community about health service utilisation."

"Giving health education about health services in different locations like health facilities, schools, community gatherings etc."

"Creating and strengthening communication with other stakeholders like non-governmental organisations."

\section{Theme 7: Supervision and record keeping}

Enhance recording and reporting system by giving on-the-job and refreshment training and supportive supervision.

Timely supportive supervision, follow-up and feedback (monitoring and evaluation) should be strengthened to enhance the commitment of health professionals.

"We have missed information due to poor documentation and negligence; anything not recorded is considered as not being done. Therefore, training and supervisions should focus on these areas too."
Some health facilities are not accessible throughout the week for $24 \mathrm{~h}$. "Even though health-seeking behaviour of the community was improved, most health posts may be closed during working hours and health centres do not provide some services the entire week. Therefore, ensuring delivery of service at all times could increase utilisation."

\section{Health professionals' opinions on health service utilisation}

Table 5 shows the opinions of health officials in terms of improving health service utilisation. The health professionals' opinions were categorised into seven thematic areas for local and regional health professionals separately. These themes were: budget allocations and alternative sources, sustainable drug and material supply, health workers capacity building, quality of services, access of health facilities, public and stakeholders involvement and collaboration, and supervision and record keeping.

\section{Discussion}

This study shows a low health service utilisation rate in one of the most densely populated areas of Ethiopia (Sidama), especially among the rural population. Febrile illnesses were prevalent diseases, and family planning cases constituted the largest proportion of the recorded diagnoses. Yet, very few non-communicable diseases were diagnosed.

Health professionals accountable for the delivery of health services in the area suggested improving the low health service utilisation by improving the quality, affordability, and accessibility of health services, improving the health professionals' skills, and introducing better diagnostic modalities. However, further studies are desired to find out if the involvement of health workers may possibly result in improved resource allocations and enhanced services.

A key strength of this study is the inclusion of all primary health care units covering the urban and rural populations. The data for the services were collected for a period of a whole year, for all types of services given, and included all governmental health centres and health posts. In addition, the comments and suggestions of health officials to improve health service utilisation were included as part of the study.

This study is not without limitations. Due to the loss of some data in three of the health centres, there might be some information bias, and there could be some underreporting for delivery and eye services. However, given the large study population, the proportion of missing data from these units is small, and this information bias is therefore probably negligible. There were also missing data on visit information. However, the number of missing cases was few compared to the total cases, therefore, they would not 
change the results. In addition, children who started their vaccination in previous fiscal year were recorded as repeat. This might cause under-reporting in vaccination coverage.

Even though the involvement of the health professionals in the research process was a new and a good experience, the political context might have introduced methodological biases. A social-desirability bias in which the health professionals responded by considering the expectations of the researchers is one of the potential biases in a country where a bureaucratic and hierarchical structure prevails. The health professionals might not have critically evaluated the day-to-day services at their institution by considering the results from the study. Instead, their focus was mainly on general, administrative, and structural solutions, overlooking some of the findings that required local or institutional recognition [40].

Moreover, the diagnosis at primary health care units was mainly based on clinical findings, as very few diagnoses were supported by laboratory findings at the health centres. Thus, the lack of laboratory support and clinical skills to diagnose, for example, typhoid fever, typhus, anaemia, diabetes mellitus, malignant disorders, and hypertension, may explain why such diseases apparently occurred rarely. There were also a few cases that came to seek health services from other areas outside the study districts, and their population was not considered in the denominator during the calculation. We assume that some people from our study districts might seek care outside their catchment. People who primarily went to private clinics and hospitals farther away were, however, not recorded, and this may be a cause of under-reporting of use of health services in the area.The overall health service utilisation rate expressed in our study is higher than the rate of primary healthcare visits in central, southern and western Ethiopia recorded 30 years ago [41]. Yet, in our study, the utilisation rate is far lower than the targeted individual outpatient visits per year of the country and of other community-based studies in Oromia and Amhara regions [5, 20, 42]. This may partly be due to the methodological difference between the studies, closure of health posts for some periods during working hours and inability to provide some services by the health centres for the entire week [43]. Patients may also prefer traditional medicine or self-treatment [42], private clinics or selfreferral to higher-level health facilities outside their catchment area. This might be due to poor quality health services in government health facilities, such as the unavailability of drugs and laboratory tests, as well as unskilled staff or an unwelcoming attitude of health professionals [13, 43, 44].

Our study indicated that the urban population used the health services more than their rural counterparts, as has been reported by others $[42,45]$. This urban- rural difference might be attributed to a higher poverty, lower accessibility and lower education for the rural population [46].

The health service utilisation by children and older age people is lower than for adult people in our study, as has been reported by others [42]. One of the explanations for this may be because these age groups are usually dependent on other people to transport them to the health facilities. Another explanation could be that older people still rely more on traditional medicine [47]. Furthermore, the unavailability of some child health services for several days of the week could also have reduced the number of cases in these groups [43].

Our study showed that more people visited health centres than health posts. This finding is in agreement with other studies done in Ethiopia and Zambia showing preference of health centres over hospitals, health posts and private facilities [21, 48]. This might be due to the proximity of health centres to the community, besides the limited services availability and absence of qualified professionals at the health posts [13]. Moreover, the community often considers the health extension workers to be involved mainly in preventive health services, such as health education and sanitation, than the curative services [49].

Consistent with our finding, some studies showed a higher health service utilisation by women than men $[20,50]$. The possible explanation for this might be the reproductive needs of women requiring separate services than men. Since most women take their children to health facilities, they might also get services or treatment for themselves [20]. The other reason might be the higher self-medication tendency of men than women [21].

The most common causes of morbidity in this study were consistent with the national study of health and health-related indicators in 2015 [51]. Diarrhoeal diseases were at the top of the list on a study done 30 years ago [41]. However, among children below 5 years of age, pneumonia was the major cause of morbidity in our study [51]. The recorded causes of morbidity may also be inaccurate due to the inadequate knowledge or skills of health professionals which may have contributed to incorrect diagnoses or over-diagnosis [52].

Family planning is the main maternal and child health service registered in our study. This finding is lower than for other sub-Saharan countries but similar to other studies done in Ethiopia [53-55]. The lower fertility rate found in the area documented in a recent study might also be an indication of improved family planning usage [56]. Besides, family planning services are available free of charge in governmental health facilities.

Antenatal care utilisation in our study was lower than most local and national studies done in the country 
except for pastoral regions [57-59]. Similarly, delivery service utilisation in this study is higher than other studies done in the country but lower than the national study of health facility delivery [58-60]. This difference might arise because our study used health facility data, whereas the other studies were community based.

Postnatal care was much lower than for other maternal health services but is similar to other national and regional studies [57, 58, 61]. This might be due to the absence of maternity waiting rooms in almost all primary health care units to admit the mother for at least $24 \mathrm{~h}$.

Even though recent studies showed an increase in the prevalence of hypertension, there were few cases of hypertension in our study [62-64]. The discrepancy in the results might be due to the inability or lack of skills or materials to make an accurate diagnosis at the primary health care units. Similarly, in the last national Ethiopian demographic and health survey (EDHS) report, the prevalence of anaemia in women of reproductive age has increased to $24 \%$ and to $57 \%$ in children [65]. However, in our study, there were very few cases with anaemia. This might be attributed to the inability to measure haemoglobin at the institutions in the study area. Likewise, the number of diabetes mellitus cases diagnosed in our study area was negligible. Similar to hypertension and anaemia, the prevalence of diabetes is most likely under-diagnosed due to the lack of clinical skills and diagnostic materials at the institutions.

\section{Conclusion}

The Ethiopian government aims to enhance the coverage of primary healthcare services in the rural communities [5]. However, there is low and unequal health service utilisation in Ethiopia. We observed low annual health service utilisation rate among rural residents, men, children and elderly, and health post users. Among the reported cases, family planning constituted the largest proportion, and non-communicable diseases were the least diagnosed group. Pneumonia was the most common recorded diagnosis among children younger than 5 years of age. Even if there is no complete agreement between registry data and the health professionals' opinions, most of the ideas overlap and give direction to improving health service utilisation. The findings of this study will help in the effort the government is undertaking to make quality health services accessible and affordable to the underserved population. Ensuring availability of drugs or medical supplies, laboratory tests and standard working procedure could increase the service usage. Moreover, supportive supervision needs to be provided, and the knowledge and skills of healthcare professionals and their diagnostic capacity need further improvement. In addition, the quality of health services should also be assessed and given priority so that the health services can be utilised by every segment of the population.

\section{Abbreviation \\ OPD: Outpatient department}

\section{Supplementary Information}

The online version contains supplementary material available at https://doi. org/10.1186/s12913-021-06846-x.

Additional file 1. List of registers.

Additional file 2. Operational definitions.

Additional file 3. Treatment at departments.

Additional file 4. Service provision by sex.

\section{Acknowledgements}

We acknowledge the Norwegian Programme for Capacity Development in Higher Education and Research for Development (NORHED) for funding this study. We are grateful for the contributions of Sidama Regional Health Bureau, Dale and Wonsho district health offices, and managers of the urban and rural health centres. We also like to extend our gratitude for all data collectors and supervisors, Mr. Lamalo Sonbala and Mr. Abera Shunkaro, for their unreserved effort during supervision. We also thank Dr. Tadiwos Hailu for his technical support during data cleaning and analysis.

\section{Authors' contributions}

HA conceptualised the idea, designed the study, acquired and analysed the data, wrote the protocol and drafted the manuscript. BL conceptualised the idea, guided the study design, the proposal writing, helped to analyse the data, drafted and validated the manuscript. MD helped in conceptualising the idea, the proposal writing, provided constructive comment in drafting the manuscript. All of the authors read and approved the submitted version of the manuscript.

\section{Funding}

The research has been funded by the Norwegian Programme for Capacity Development in Higher Education and Research for Development (NORHED). The funder has no role in the design, data collection, analysis, interpretation and writing of the manuscript.

\section{Availability of data and materials}

The datasets used and/or analysed during the current study are available from the corresponding author on reasonable request.

\section{Declarations}

\section{Ethics approval and consent to participate}

Ethical clearance was obtained from the Institutional Review Board at the College of Medicine and Health Sciences of Hawassa University (Reference number IRB/022/10) and the Regional Ethics Committee for Medical and Health Research in Norway REK Vest (2018/67/REK vest). Permission letters were obtained from the Sidama Zone Health Department, Dale and Wonsho woreda (district) health offices to access the secondary data from all health facilities. The above mentioned ethical committees ruled that no formal consent is required for secondary data use. For the qualitative study participants, a written informed consent was obtained after giving information about the objective of the study, the role of the participant, risk or discomfort, benefit, confidentiality, and voluntary participation. The interview took place in separate room after getting their permission. All the methods used in this study were in accordance with relevant guidelines and regulations. No minors were asked or involved directly. There is no personal identifier in the data set. The data collection tool was kept in a secure place to maintain the confidentiality of information obtained from the participants. 


\section{Competing interests}

The authors declare that they have no competing interests.

Received: 22 November 2020 Accepted: 28 July 2021 Published online: 06 August 2021

\section{References}

1. World Health Organization. Framework on integrated, people-centred health services:Sixty-ninth World Health Assembly Provisional agenda item 16.1. Geneva: World Health Organization; 2016

2. World Health Organization. Universal health coverage (UHC). 2019 [cited 2020 Mar 4]; Available from: https://www.who.int/news-room/fact-sheets/ detail/universal-health-coverage-(uhc).

3. Bhuiya A, Hanifi SMA, Urni F, Mahmood SS. Three methods to monitor utilization of healthcare services by the poor. Int J Equity Health. 2009;8(1): 29. https://doi.org/10.1186/1475-9276-8-29.

4. Abayneh S, Lempp H, Alem A, Kohrt BA, Fekadu A, Hanlon C. Developing a theory of change model of service user and caregiver involvement in mental health system strengthening in primary health care in rural Ethiopia. Int J Ment Health Syst. 2020;14(1):1-17.

5. Ethiopian Federal Ministry of Health. Health sector transformation plan (2015/16-2019/20). Addis Ababa: Federal Ministry of Health; 2015.

6. Donnelly J. Ethiopia gears up for more major health reforms. Lancet. 2011; 377(9781):1907-8. https://doi.org/10.1016/S0140-6736(11)60795-2.

7. Ethiopian Federal Ministry of Health. Ethiopia's health sector: excellent returns on your development funding. Addis Ababa, Ethiopia: Federal Ministry of Health; 2013.

8. National Planning Commission. Ethiopia 2017 Voluntary National Review on SDGs: Government Commitments, National Ownership and Performance Trends. Addis Ababa: Federal Democratic Republic of Ethiopia National Planning Commission; 2017. p. 1-45.

9. Alebachew A, Waddington C. Improving health system efficiency: Ethiopia: human resources for health reforms. Geneva: World health Organization; 2015.

10. Ministry of Health of Ethiopia. Essential Health Services Package for Ethiopia. 2019.

11. World Health Organization. World Health statistics 2014: Health service coverage. Geneva: World Health Organization; 2014.

12. Eregata GT, Hailu A, Memirie ST, Norheim OF. Measuring progress towards universal health coverage: national and subnational analysis in Ethiopia. BMJ Glob Heal. 2019;4(6):1-9.

13. Federal Democratic Republic of Ethiopia Ministry of Health. Ethiopian Health Accounts Household Health Service Utilization and Expenditure Survey Brief 2015/2016. Addis Ababa: Federal Democratic Republic of Ethiopia Ministry of Health; 2017. p. 1-9.

14. World Health Organization. Global Reference List of 100 Core Health Indicators (plus health-related SDGs). Geneva: World Health Organization; 2018.

15. World Health Organization. Monitoring the Building Blocks of Health Systems: a Handbook of Indicators and Their Measurement Strategies, vol. 35. Geneva: World Health Organization; 2010.

16. Moses MW, Pedroza P, Baral R, Bloom S, Brown J, Chapin A, et al. Funding and services needed to achieve universal health coverage: applications of global, regional, and national estimates of utilisation of outpatient visits and inpatient admissions from 1990 to 2016, and unit costs from 1995 to 2016 Lancet Public Heal. 2019;4(1):e49-73. https://doi.org/10.1016/S2468-2667(1 8)30213-5.

17. Ethiopian Federal Ministry of Health. Fact Sheets: Fact sheet-Ethiopia 2015. 2019 [cited 2020 Mar 4]; Available from: http://www.moh.gov.et/ejcc/en/ node/15

18. World Health Organization. Eastern Mediterranean Region Indicator and Metadata Registry. 2016 [cited 2020 Mar 5]. Available from: http://gis.emro. who.int/EMRIMR/Indicators.aspx?i=1

19. Louis G. Pol, Richard K. Thomas. The demography of health and health care. 3rd. Kenneth C. Land. New York: Springer; 2013 p. 1-295. https://doi.org/10.1 007/978-90-481-8903-8

20. Girma F, Jira C, Girma B. Health services utilization and associated factors in Jimma zone, south West Ethiopia. Ethiop J Health Sci. 2011;21(Suppl 1):8594.

21. Masiye F, Kaonga O. Determinants of healthcare utilisation and out-ofpocket payments in the context of free public primary healthcare in
Zambia. Int J Heal Policy Manag. 2016;5(12):693-703. https://doi.org/10.151 71/ijhpm.2016.65.

22. Cook N, Siddiqi N, Twiddy M, Kenyon R. Patient and public involvement in health research in low and middle-income countries: a systematic review. BMJ Open. 2019;9:e026514.

23. Bergmeier $H$, Vandall-Walker V, Skrybant M, Teede H, Bailey C, Baxter J-A, et al. Global Health in preconception, pregnancy and postpartum Alliance: development of an international consumer and community involvement (CCI) framework. Res Involv Engagem. 2020;1:1-13.

24. Miller CL, Mott K, Cousins M, Miller S, Johnson A, Lawson T, et al. Integrating consumer engagement in health and medical research - an Australian framework. Heal Res Policy Syst. 2017;15(1):1-6.

25. Boote J, Baird W, Sutton A. Public involvement in the systematic review process in health and social care: A narrative review of case examples. Health Policy. 2011;102:105-16.

26. Regidor E, de la Fuente L, Gutiérrez-Fisac JL, de Mateo S, Pascual C, Sánchez-Payá J, et al. The role of the public health official in communicating public health information. Am J Public Health. 2007; 97(Suppl 1):S93.

27. Lindtjørn B, Tadesse M, Loha E. Developing a sustainable PhD programme: experiences from southern Ethiopia. In: Halvorsen T, Orgeret KS, editors. Sharing knowledge, transforming societies: the Norhed Programme 20132020: Bergen, African Minds; 2019. p. 442-56.

28. Lindtjørn B. Could devolving pneumonia treatment to local health centres reduce mortality in developing countries? Acta Paediatr Int J Paediatr. 2020; 00:1-2. https://doi.org/10.1111/apa.15584.

29. Staniszewska S, Brett J, Simera I, Seers K, Mockford C, Goodlad S, et al. GRIPP2 reporting checklists: tools to improve reporting of patient and public involvement in research. BMJ. 2017;358:1-7.

30. Central Statistical Agency, Ethiopian Development Research Institute, International Food Policy Research Institute. Population \& Housing Census: ATLAS OF ETHIOPIA 2007. Washington, DC; Addis Ababa: International Food Policy Research Institute (IFPRI), Central Statistical Agency; 2010. https://doi. org/10.2499/9780896299276.

31. Central Statistical Agency. 2007 Population and Housing Census of Ethiopia: Section-B Population. Addis Ababa, Ethiopia: Office of the Population Census Commission; 2007.

32. Federal Democratic Republic of Ethiopia Population Census Commisssion. Summary and Statistical Report of the 2007 Population and Housing Census: Population Size by Age and Sex. Addis Ababa: Office of the Population Census Commision; 2008

33. Sidama Zone Finance and Economic Development Office. Sidama zone administration socio-economic profile 2014/15. Hawassa: SNNPR; 2016.

34. Dalle Woreda Finance and Economic Development Office. The development of social and economical information of Dalle woreda. Hawassa: SNNPR; 2016

35. Workie NW, Ramana GNV. The health extension program in Ethiopia. Washington, DC: The Universal Health Coverage Studies Series; 2013.

36. World Health Organization. International statistical classification of diseases and related health problems- 10th revision, vol. 3. 5th ed. Geneva: World Health Organisation; 2016.

37. Federal Democratic Republic of Ethiopia Ministry of Health. National Classification of diseases (NCoD). Compact Ed. Addis Ababa: Ministry of Health; 2017.

38. Central Statistical Agency. National Census. Ethiopia, Addis Ababa: Office of the Population Census Commission; 2007.

39. Federal Ministry of Health. HMIS Indicator reference guide technical standards: area 1. Addis Ababa, Ethiopia: Ethiopian Ministry of Health; 2017.

40. Østebø MT, Cogburn MD, Mandani AS. The silencing of political context in health research in Ethiopia: Why it should be a concern. Health Policy and Planning. 2018;33:258-70.

41. Kloos H. Utilization of selected hospitals, health centres and health stations in central, southern and Western Ethiopia. Soc Sci Med. 1990;31(2):101-14. https://doi.org/10.1016/0277-9536(90)90052-T.

42. Fantahun M, Degu G. Health service utilization in Amhara region of Ethiopia. Ethiop J Heal Dev. 2004;17(2):141-7. https://doi.org/10.4314/ejhd.v17i2.9855.

43. Hailemariam S, Gebeyehu Y, Loha E, Johansson KA, Lindtjørn B. Inadequate management of pneumonia among children in South Ethiopia: findings from descriptive study. BMC Health Serv Res. 2019;19(1):1-14.

44. Carter JY, Lema OE, Wangai MW, Munafu CG, Rees PH, Nyamongo JA. Laboratory testing improves diagnosis and treatment outcomes in primary 
health care facilities. Afr J Lab Med. 2011;1 (1):1-6. https://doi.org/10.4102/a jlm.v111.8.

45. Alebachew, Abebe, Laurel Hatt, Matt Kukla SN. Universal health coverage low-income Context: an Ethiopian case study. Bethesda: Health Finance \& Governance Project, Abt Associates Inc; 2014. p. 1-94.

46. Begashaw B, Tessema F, Gesesew HA. Health care seeking behavior in Southwest Ethiopia. PLoS One. 2016;11(9):e0161014. https://doi.org/10.1371/ journal.pone.0161014.

47. James PB, Wardle J, Steel A, Adams J. Traditional, complementary and alternative medicine use in sub-Saharan Africa: a systematic review. BM Glob Heal. 2018;3(5):895.

48. Mebratie AD, Van De Poel E, Yilma Z, Abebaw D, Alemu G, Bedi AS. Healthcare-seeking behaviour in rural Ethiopia: Evidence from clinical vignettes. BMJ Open. 2014;4(2):e004020. https://doi.org/10.1136/bmjopen-2 013-004020

49. Medhanie AA, Spigt M, Kifle YT, Schaay N, Sanders D, Blanco M, et al. The Contribution of Health Extension Workers in Improving the Utilization of Maternal Health Services in Rural Areas of Tigray, Ethiopia. In: Labonte R, PC SD, SN, editors. Revitailizing health for all: Case Studies of the Struggle for Comprehensive Primary Health Care. Canada: University of Toronto Press Toronto; 2017. p. 237-54.

50. Bazie GW, Adimassie MT. Modern health services utilization and associated factors in north East Ethiopia. PLoS One. 2017;12(9):e0185381. https://doi. org/10.1371/journal.pone.0185381.

51. Federal Ministry of Health. Health and Health Related Indicators: Better Information, Better Decision, Better Health: Version 1. Addis Ababa, Ethiopia: Policy Planning Directorate, Federal Ministry of Health; 2015.

52. Tariku A, Okwaraji YB, Worku A, Biks GA, Åke Persson L, Berhane Y. Prevention and treatment of suspected pneumonia in Ethiopian children less than five years from household to primary care. Acta Paediatr. 2020;00: $1-9$.

53. Bayray A, Meles KG, Sibhatu Y. Magnitude and risk factors for hypertension among public servants in Tigray. Ethiopia: A cross-sectional study PLoS One. 2018;13(10):e0204879. https://doi.org/10.1371/journal.pone.0204879.

54. Endriyas M, Eshete A, Mekonnen E, Misganaw T, Shiferaw M, Ayele S. Contraceptive utilization and associated factors among women of reproductive age group in southern nations nationalities and peoples' region, Ethiopia: cross-sectional survey, mixed-methods. Contracept Reprod Med. 2017;2(10):1-9.

55. Ahmed S, Choi Y, Rimon JG, Alzouma S, Gichangi P, Guiella G, et al. Trends in contraceptive prevalence rates in sub-Saharan Africa since the 2012 London summit on family planning: results from repeated cross-sectional surveys. Lancet Glob Heal. 2019;7(7):e904-11. https://doi.org/10.1016/ S2214-109X(19)30200-1.

56. Areru HA, Dangisso MH, Lindtjørn B. Births and deaths in Sidama in southern Ethiopia: findings from the 2018 Dale-Wonsho Health and Demographic Surveillance System (HDSS). Glob Health Action. 2020;13(1): 1833511.

57. Regassa N. Antenatal and postnatal care service utilization in southern Ethiopia: a population-based study. Afr Health Sci. 2011;11(3):390-7.

58. Ethiopian Public Health Institute (EPH))[Ethiopia] and ICF. Ethiopia Min Demographic and Health Survey 2019: Key indicators. Rockville: EPHI and ICF; 2019.

59. Umer A, Zinsstag J, Schelling E, Tschopp R, Hattendof J, Osman K, et al. Antenatal care and skilled delivery service utilisation in Somali pastoral communities of eastern Ethiopia. Trop Med Int Heal. 2019;25(3):328-37.

60. Tesfaw N, Gizachew A, Kassa GM, Abajobir AA. Skilled delivery service utilization and associated factors among mothers who gave birth in the last two years in Northwest Ethiopia. Ethiop J Health Sci. 2018;28(4):423-32. https://doi.org/10.4314/ejhs.v28i4.8.

61. Worku AG, Yalew AW, Afework MF. Factors affecting utilization of skilled maternal care in Northwest Ethiopia: a multilevel analysis. BMC Int Health Hum Rights. 2013;13(20):1-11.

62. Belachew A, Tewabe T, Miskir Y, Melese E, Wubet E, Alemu S, et al. Prevalence and associated factors of hypertension among adult patients in Felege-Hiwot comprehensive referral hospitals, northwest, Ethiopia: a crosssectional study. BMC Res Notes. 2018;11(876):1-6.

63. Kibret KT, Mesfin YM. Prevalence of hypertension in Ethiopia: a systematic meta-analysis. Public Health Rev. 2015;36:1-12.
64. Zekewos A, Egeno T, Loha E. The magnitude of hypertension and its risk factors in southern Ethiopia: a community based study. Wang W. PLoS One. 2019;14(8):e0221726.

65. Central Statistical Agency (CSA) [Ethiopia] and ICF. Ethiopia Demographic and Health Survey 2016. Addis Ababa, Ethiopia, and Rockville, Maryland: CSA and ICF; 2016.

\section{Publisher's Note}

Springer Nature remains neutral with regard to jurisdictional claims in published maps and institutional affiliations.
Ready to submit your research? Choose BMC and benefit from:

- fast, convenient online submission

- thorough peer review by experienced researchers in your field

- rapid publication on acceptance

- support for research data, including large and complex data types

- gold Open Access which fosters wider collaboration and increased citations

- maximum visibility for your research: over $100 \mathrm{M}$ website views per year

At BMC, research is always in progress.

Learn more biomedcentral.com/submissions 